\title{
Analysis of the impact of vehicles on air pollution in Ulan-Ude
}

\author{
Liudmila Grigoryeva ${ }^{1, *}$, Anfisa Dmitrieva ${ }^{1}$, Oyuna Ayurova ${ }^{1}$, Valerii Hertuev ${ }^{1}$, and Darma \\ Markhaev ${ }^{1}$ \\ ${ }^{1}$ Buryat State University after Dorzhi Banzarov, 24a Smolin St., 670000 Ulan-Ude, Russia
}

\begin{abstract}
In recent years, urban ecology has become one of the key indicators for evaluating the citizens' quality of life. The article studies the road network situation in Ulan-Ude, as well as the impact of vehicle emissions on the quality characteristics of the city's atmospheric air from 2010 to 2019. The features of the application of various methods for assessing the level of pollutants from vehicles on the example of Ulan-Ude are described. The dynamics of changes in the main pollutants including sulfur dioxide, carbon monoxide, nitrogen monoxides, and other impurities, is revealed. Ways to reduce the air pollution from vehicles in Ulan-Ude are proposed.
\end{abstract}

\section{Introduction}

The problem of air pollution is of particular importance in terms of the ecological situation in populated localities. The share of vehicle emissions in urban air pollution is constantly growing. Along with the increase in individual construction and the growth of the road network, the number of vehicles of all types is also rising.

Ulan-Ude is the capital of the Republic of Buryatia, located in Eastern Siberia, $150 \mathrm{~km}$ from Lake Baikal. According to Rosstat, the population of Buryatia in 2018 was 984,511 people. The Ulan-Ude agglomeration includes the city of Ulan-Ude and the nearby municipal districts, in particular, Tarbagataisky district, Zaigraevsky district, Ivolginsky district, and Pribaikalsky district. The total area of the agglomeration is over $27,800 \mathrm{~km}^{2}$, and the population is 526,000 people.

The level of motorization of the population of Ulan-Ude, as well as of most Russian cities, has risen many times over the past eighteen years. The growth of this indicator is mainly due to the spike in the number of personal cars in the urban community. From 2000 to 2018, the city's total number of vehicles increased by a factor of more than 3.8.

The study of the influence of vehicles on urban air pollution is attracting more and more attention of researchers. There is a wide variety of methods for assessing air pollution from vehicles. However, it should be noted that there is no unified methodology for calculating pollutants from vehicles, which would lay the foundation for a system of monitoring and controlling the environment by supervisory state bodies [1-9].

\footnotetext{
* Corresponding author: zzk-446@1ist.ru
} 


\section{Materials and methods}

The given analysis of the atmospheric air in Ulan-Ude is based on open statistical data from Rosstat for the Russian Federation and the Republic of Buryatia, data from the Buryat Center for Hydrometeorology and Environmental Monitoring, which is a branch of the Federal State-funded Institution "Zabaikalskoye Department for Hydrometeorological Service", data from the Center for Hygiene and Epidemiology in the Republic of Buryatia, as well as the results of the researchers' field studies.

The methodological basis for the study includes methods of systemic and statistical analyses. Additionally, there was used an assessment of the Ulan-Ude atmospheric air along the main highways on the basis of field observations, taking into account the seasonality and different times of day. The calculation of the amount of pollutant emissions was carried out in accordance with State standard GOST R 56162-2014 entitled "Emissions of pollutants into the atmosphere. A method of calculating vehicle emissions for summary estimate in urban localities".

\section{Results}

In 2019, the Priority List of cities with the highest level of air pollution was compiled based on air samples from 250 Russian cities (information from the Federal Service for Hydrometeorology and Environmental Monitoring). Eighteen cities including Ulan-Ude with a combined population of 3.3 million joined the list.

The analysis of the dynamics of the vehicle fleet, based on the data from the Office of the State Traffic Safety Inspectorate of the Ministry of Internal Affairs in the Republic of Buryatia, for 14 years indicates that the total number of cars in Ulan-Ude has burgeoned by 131,256 units, or by $183.4 \%$ (46 311 units in 2003, 177567 units in 2017) (Figure 1).

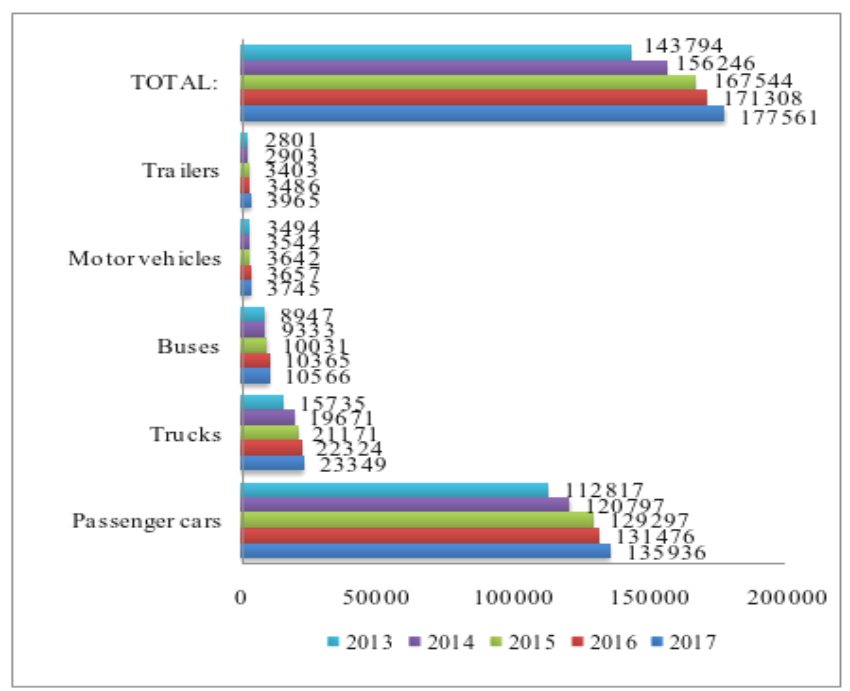

Fig. 1. Dynamics of the vehicle fleet registered in Ulan-Ude from 2013 to 2017, units 


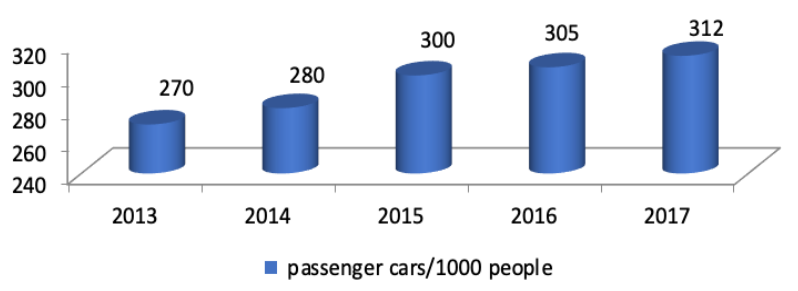

Fig. 2. Dynamics of Ulan-Ude citizens' level of motorization

The level of motorization of Ulan-Ude residents in terms of the number of the passenger cars registered is steadily increasing, in proportion to the growth in the number of citizens and the agglomeration territory (Figure 2).

However, with the rise in the quantity of various types of vehicles, some problems are escalating, which leads to lowering the quality of peoples' life. The carrying capacity of the main transport routes of Ulan-Ude is annually decreasing, whereas the standard duration of a trip to common destinations is increasing. Also, travelling is becoming less comfortable due to the constantly growing atmospheric pollution and insufficient public transport. As shown by the earlier analysis of the structure of pollutants in Ulan-Ude, vehicle emissions account for a slightly more than $45 \%$ of the total air pollution in Ulan-Ude. The emissions from all types of vehicles in the urban agglomeration dominate in the carbon monoxide air pollution (Table 1) [10-11].

Table 1. Dynamics of pollutants in the atmospheric air in Ulan-Ude (average annual daily concentration in fractions of MPC)

\begin{tabular}{|l|c|c|c|c|}
\hline Indicator & 2017 & 2018 & 2019 & $\begin{array}{c}2019 \\
\text { compared to 2017, \% }\end{array}$ \\
\hline Nitrogen dioxide & 0.93 & 1 & 0.95 & 2.15 \\
\hline Particulate matter & 1.75 & 1.88 & 1.48 & -15.43 \\
\hline Carbon monoxide & 0.17 & 0.17 & 0.19 & 11.76 \\
\hline Sulfur dioxide & 0.26 & 0.36 & 0.29 & 11.54 \\
\hline Formaldehyde & 1.00 & 1.30 & 1.2 & 20.00 \\
\hline Phenol & 1 & 1 & 0.56 & -44.00 \\
\hline Benzopyrene & 7.6 & 10.2 & 11.95 & 57.24 \\
\hline Nitrogen monoxide & 0.32 & 0.42 & 0.41 & 28.13 \\
\hline Ozone & 0.9 & 1.07 & 1.17 & 30.00 \\
\hline Ammonia & 0.2 & 0.10 & 0.02 & -90.00 \\
\hline Carbon (char) & 0.28 & 0.34 & 0.48 & 71.43 \\
\hline Hydrogen sulfide $\left(\mathrm{mg} / \mathrm{m}^{3}\right)^{*}$ & 0.001 & 0.002 & 0.001 & 0.00 \\
\hline Particulate matter PM10 & 1.2 & 1.13 & 1.07 & -10.83 \\
\hline Particulate matter PM2,5 & 1.34 & 1.37 & 1.34 & 0.00 \\
\hline
\end{tabular}

The analysis of references related to the impact of vehicles on the level of air pollution over the past decade has allowed emphasizing two research works carried out by two different groups of researchers.

In 2012, at the request of the Ulan-Ude Administration, a group of specialists led by M. V. Volkodaeva from St. Petersburg Institute of Applied Ecology and Hygiene made the first comprehensive assessment of the city's atmospheric air, which considered the sources of pollution [12].

The research determined vehicle emissions and conducted special field surveys. Motor 
transport flows on the main highways of Ulan-Ude in 2012 were divided into the following groups: the lowest intensity was observed in Domostroitelnaia Street (the settlement of Silikatny) ( $<=70$ vehicles / hour), on nine highways there were less than a thousand vehicles per hour; on five highways the number of vehicles per hour ranged from 1,000 to 1,500 vehicles per hour; on eight highways this indicator ranged from 1,500 to 2,000; on fifteen highways it was from 2,000 to 5,000; and the highest traffic intensity ( $>5000$ cars / hour) was in Babushkina Street.

The result of this study demonstrates that it is passenger cars that prevail in the total intensity of the traffic flow in Ulan-Ude (77\%). The second most intensively used type of vehicles is trucks $(21 \%)$, with approximately half of them being diesel ones (11\%).

Additional result of the study is the calculation of urban air pollution for a number of pollutants, such as benzopyrene and sulfur dioxide, carbon monoxide, nitrogen dioxide, nitrogen oxide, hydrocarbons (gasoline and kerosene), formaldehyde, and carbon char. Field observations were made on 717 sections of city highways. The analysis of the calculation results showed that the most significant pollutant from the above group of substances was nitrogen dioxide.

In 2013, another investigation of the main pollutants was conducted by N. N. Tumureeva and S. E. Sanzhieva [13]. In this study, carbon monoxide (II) emissions were calculated to determine the dynamics of indicators of the atmospheric air pollution from most types of vehicles in Ulan-Ude applying the method for determining the level of carbon monoxide concentration [14]. The results of the calculations on basic air pollutants in Ulan-Ude for ten years are presented in Table 2 .

Table 2. Yearly comparative characteristic of CO in Ulan-Ude

\begin{tabular}{|c|c|c|c|c|c|c|c|}
\hline \multirow[t]{3}{*}{ № } & \multirow[t]{3}{*}{ Name } & \multicolumn{6}{|c|}{ Yearly $\mathrm{CO}$ concentration $(\mathrm{COC}), \mathrm{mg} / \mathrm{m}^{3}$} \\
\hline & & \multicolumn{3}{|c|}{2003} & \multicolumn{3}{|c|}{2013} \\
\hline & & $\begin{array}{c}\text { mornin } \\
\mathrm{g}\end{array}$ & $\begin{array}{c}\text { afternoo } \\
n\end{array}$ & $\begin{array}{c}\text { evenin } \\
\mathrm{g}\end{array}$ & $\begin{array}{c}\text { mornin } \\
\mathrm{g}\end{array}$ & $\begin{array}{c}\text { afternoo } \\
n\end{array}$ & $\begin{array}{c}\text { evenin } \\
\mathrm{g}\end{array}$ \\
\hline 1 & Smolina St. & 26.5 & 31.75 & 27.68 & 94.7 & 111.2 & 118.3 \\
\hline 2 & Babushkina St. & 127.56 & 109.92 & 113.97 & 253.6 & 230.02 & 302.7 \\
\hline 3 & Tereshkovoi St. & 21.73 & 10.82 & 10.98 & 168.8 & 183.3 & 186.6 \\
\hline 4 & $\begin{array}{l}\text { Kluchevskaia } \\
\text { St. }\end{array}$ & 29.41 & 31.14 & 28.82 & 146.6 & 149.6 & 150.6 \\
\hline 5 & $\begin{array}{l}\text { 50-letia } \\
\text { Oktiabria Ave. }\end{array}$ & 84.04 & 78.26 & 54.06 & 123.8 & 124.04 & 126.4 \\
\hline 6 & $\begin{array}{l}\text { Komsomolskai } \\
\text { a St. }\end{array}$ & 5.6 & 4.21 & 6.54 & 30.8 & 31.56 & 31.35 \\
\hline 7 & $\begin{array}{l}\text { Nikolaia } \\
\text { Petrova St. }\end{array}$ & 20.35 & 18.61 & 28.54 & 81.5 & 75.6 & 76.7 \\
\hline 8 & $\begin{array}{l}\text { Average daily } \\
\mathrm{COC}\left(\mathrm{mg} / \mathrm{m}^{3}\right)\end{array}$ & 45.03 & 40.67 & 38.66 & 128.54 & 129.33 & 141.81 \\
\hline 9 & $\begin{array}{l}\text { Average } \\
\text { annually } \\
\left(\mathrm{mg} / \mathrm{m}^{3}\right)\end{array}$ & & 41.45 & & & 133.23 & \\
\hline
\end{tabular}

The results by N.N. Tumureeva and S. E. Sanzhieva showed that the main source of carbon monoxide is the vehicles on the busiest highways in Ulan-Ude. Also, the calculated value of $\mathrm{CO}$ (carbon monoxide) in the atmospheric air is ten times higher than that of a onetime indicator of the maximum permissible concentration (MPC) and average daily 
indicators.

\section{Discussion}

A two-stage study of the situation was conducted to assess the impact of vehicles on air pollution in Ulan-Ude. At the first stage, an analysis of the capacity of the Ulan-Ude highways was carried out on the basis of field observations throughout the year, taking into account the seasonality and different times of day in order to identify bottlenecks.

The existing road network of the city has multiple drawbacks caused by a discrepancy in the road network capacity. The Ulan-Ude road network was designed and constructed in the last century. Thus, nowadays, with the spiking number of vehicles, many bottlenecks appear.

The survey of the Ulan-Ude street and road network shows its significantly uneven development throughout the entire territory of the urban agglomeration. This is due to some natural geographic reasons. The city is surrounded by mountains; it is located at the confluence of two rivers, the Uda and the Selenga [15]; besides, the city is divided by the Trans-Siberian railway.

The total length of the street and road network of the Ulan-Ude agglomeration is over 538 $\mathrm{km}$, including $380.4 \mathrm{~km}$ of the roads with improved coverage; the length of the main streets and roads is $253.92 \mathrm{~km}$.

The results of a full-scale survey of the city's road network identified the bottlenecks in which long traffic jams most often occur during peak hours. The busiest Ulan-Ude streets as well as the traffic characteristics calculated are presented in Table 3 (based on the data of the Ulan-Ude Transport Model).

Table 3. Ulan-Ude busiest streets, bottlenecks, and their capacity

\begin{tabular}{|c|c|c|c|c|}
\hline № & Streets & $\begin{array}{l}\text { Road traffic and vehicle } \\
\text { intensity, unit/hour } \\
\text { on peak period }\end{array}$ & $\begin{array}{l}\text { Lane } \\
\text { number }\end{array}$ & $\begin{array}{l}\text { Vehicle travel } \\
\text { time, } \\
\text { min }\end{array}$ \\
\hline 1 & $\begin{array}{l}\text { 50-letia Oktiabria Avenue } \\
- \\
\text { Erbanova Street } \\
\text { (Kommunisticheskaia } \\
\text { Street-Gagarina Street) }\end{array}$ & $\begin{array}{l}\text { From the city center }-1762 \text {; } \\
\text { To the city center }-2333\end{array}$ & 2 & $\begin{array}{l}\text { morning }-10- \\
15 ; \\
\text { afternoon }-10- \\
15 ; \\
\text { evening }-10-15\end{array}$ \\
\hline 2 & Ivolginskaia Street & $\begin{array}{l}\text { From the city center }-760 ; \\
\text { To the city center }-2100\end{array}$ & 2 & $\begin{array}{l}\text { morning }-10- \\
15 \text {; } \\
\text { evening }-10-15 \text {; }\end{array}$ \\
\hline 3 & $\begin{array}{l}\text { Blinova Street } \\
\text { (Verkhniaia Berezovka - } \\
\text { Avtomobilistov Avenue) }\end{array}$ & $\begin{array}{l}\text { From the city center }-966 \text {; } \\
\text { To the city center }-1430\end{array}$ & 1 & morning $-10-15$ \\
\hline 4 & $\begin{array}{l}\text { Avtomobilistov Avenue } \\
\text { (Botanicheskaia Street - } \\
\text { Kluchevskaia Street) }\end{array}$ & $\begin{array}{l}\text { From the city center }-1430 \text {; } \\
\text { To the city center }-1410\end{array}$ & 2 & $\begin{array}{l}\text { morning }-10- \\
15 ; \\
\text { evening }-10-15\end{array}$ \\
\hline 5 & Tereshkovoi Street & $\begin{array}{l}\text { From the city center }-1200 ; \\
\text { To the city center }-1320\end{array}$ & 2 & morning $-10-15$ \\
\hline 6 & $\begin{array}{l}\text { Babushkina Street } \\
\text { (Tereshkovoi Street - } \\
\text { Orlovskaia Street) }\end{array}$ & $\begin{array}{l}\text { From the city center }-610 \\
\text { To the city center }-870\end{array}$ & 2 & morning $-15-20$ \\
\hline 7 & Trubacheeva Street & $\begin{array}{l}\text { From the city center }-580 \\
\text { To the city center }-870\end{array}$ & 1 & $\begin{array}{l}\text { morning }-15- \\
20 ; \\
\text { evening }-15-20\end{array}$ \\
\hline
\end{tabular}




\begin{tabular}{|c|l|l|c|c|}
\hline № & Streets & $\begin{array}{c}\text { Road traffic and vehicle } \\
\text { intensity, unit/hour } \\
\text { on peak period }\end{array}$ & $\begin{array}{c}\text { Lane } \\
\text { number }\end{array}$ & $\begin{array}{c}\text { Vehicle travel } \\
\text { time, } \\
\text { min }\end{array}$ \\
\hline 8 & Dorozhnaia Street & $\begin{array}{l}\text { From the city center }-430 ; \\
\text { To the city center }-1200\end{array}$ & 2 & $\begin{array}{l}\text { morning }-15- \\
20 ; \\
\text { evening }-15-20\end{array}$ \\
\hline
\end{tabular}

At the second stage, the level of pollutants from motor vehicle emissions was calculated. The researchers took into account the previous field observations on the main Ulan-Ude highways and applied the selected method. The aggregate calculation of emissions of harmful substances from vehicles in Ulan-Ude in 2020 in terms of the annual volume is the following: $3,957,000$ tons / year by the level of carbon dioxide (CO) and 1,476,000 tons / year by the level of nitrogen oxide (NOx).

In addition, it should be noted that the growing traffic intensity on the Ulan-Ude highways contributes to an increase in the concentration of suspended solids in the city's atmosphere due to their destruction and abrasion of road surfaces. At the moment, more than $50 \%$ of the road coverage do not meet the normative requirement.

\section{Conclusion}

The aggregate calculation of the number of pollutants from various types of vehicles in the air of Ulan-Ude was made on the basis of State standard GOST R 56162-2014 entitled "Emissions of pollutants into the atmosphere. A method of calculating vehicle emissions for summary estimate in urban localities".

Based on the results of field observations of the Ulan-Ude road network, calculations of the level of air pollutants were made. The calculation data indicate that the territories where more than one-time excess of the MPC for nitrogen dioxide is observed are located mainly in the central part of Ulan-Ude, that is Sovetsky district, as well as along the main highways connecting all three districts of the city (Sovetsky district, Zheleznodorozhnyi district, and Oktyabrsky district). The air pollution with $\mathrm{CO}$ (carbon monoxide) and formaldehyde is significantly lower compared to the level of nitrogen dioxide pollution and is observed in the entire road network with concentrations from 0.1 to $1.5 \mathrm{MPC}$.

The given research testifies to a global environmental problem in Ulan-Ude, that is a constantly increasing level of air pollutants. More than half of the total number of urban air pollutants is produced by the steadilyly growing vehicle fleet. Moreover, the problem of vehicle emissions is exacerbated by numerous bottlenecks in the city's road network. Most highways are located next to the residential area. Consequently, the threat to the health of the residents of Ulan-Ude is quite high. The emissions into the air from heating sources are seasonal, whereas vehicle emissions occur all year round.

The investigation was conducted as part of a 2020 grant for innovative scientific research at Dorzhi Banzarov Buryat State University.

\section{References}

1. Q.J. Zhang, L. Wu, Z.W. Yang, C. Zou, X. Liu, K.S. Zhang, H.J. Mao, Transportation research part D-transportation and environment 43, 40-48 (2016)

2. R. Borck, Regional Science and Urban Economic 77(C), 356-366 (2019)

3. L. Duque, H. Relvas, C. Silveira, J. Ferreira, A. Monteiro, C. Gama, S. Rafael, S. Freitas, C. Borrego, A.I. Miranda, Atmospheric Environment 127, 196-204 (2016) doi: 10.1016/j.atmosenv.2015.12.043. 
4. C. Sun, W. Zhang, X. Fang, X. Gao, M. Xue, Energy Policy 135 (2019) doi: 10.1016/j.enpol.2019.110998

5. M. Mathissen, V. Scheer, U. Kirchner, et al., Atmospheric Environment 59, 232-242 (2012)

6. H. Shiraki, K. Matsumoto, Y. Shigetomi, T. Ehara, Y. Ochi, Y. Ogawa, Applied Energy, Elsevier 259(C) (2020) doi: 10.1016/j.apenergy.2019.114196

7. E. Dons, M. Laeremans, J. Pablo Orjuela, I. Avila-Palencia, A. de Nazelle, Mark Nieuwenhuijsen, M. Van Poppel, G. Carrasco-Turigas, A. Standaert, P. De Boever, T. Nawrot, L. Int Panis, Atmospheric Environment 213, 424-432 (2019)

8. W. Kam, J. W. Liacos, J. J. Schauer, et al., Atmospheric Environment 55, 90-97 (2012)

9. G. Titos, H. Lyamani, L. Drinovec, F.J. Olmo, G. Močnik, L. Alados-Arboledas, Atmospheric Environment 114, 19-31 (2015)

10. Governmental report. Environmental health and safety of the Republic of Buryatia in 2019. Ministry of Natural Resources of the Republic of Buryatia. 2020.

11. Governmental report. Environmental health and safety of the Republic of Buryatia in 2018. Ministry of Natural Resources of the Republic of Buryatia. 2019.

12. Citywide consolidated volume "Atmosphere protection and maximum permitted emissions (MPA) of Ulan-Ude." St. Petersburg: Institute of applied ecology and hygiene, 473 (2013).

13. N.N. Tumereeva, S.I. Sanzhieva, Bulletin of Buryat State University 4, 237-243 (2015)

14. F. Amato, M. Pandolfi, T. Moreno, et al., Atmospheric Environment 45, 6777-6787 (2011)

15. A.A. Aiurzhanaev, S.N. Aiusheeva, V.S. Batomunkuev, I.A. Belozertseva, A.N. Beshentsev, D.A. Darbalaeva, Z.S. Eremko, A.S. Mikheeva, S.G. Sanzhieva, B.Z. Tsydypov, Geography and natural resources 5, 225-233 (2016) 